\title{
PENGARUH MODEL PEMBELAJARAN BERBASIS MASALAH TERHADAP KEMAMPUAN BERPIKIR TINGKAT TINGGI DAN KEMAMPUAN MENANYA DALAM PEMBELAJARAN MATEMATIKA KELAS V SD
}

\author{
L. Sugianti ${ }^{1}$, Sariyasa ${ }^{2}$, A.A.I.N Marhaeni ${ }^{3}$ \\ Program Studi Pendidikan Dasar, Program Pascasarjana \\ Universitas Pendidikan Ganesha \\ Singaraja, Indonesia \\ e-mail: sugianti.taty@gmail.com, \\ sariyasa@pasca.undiksha.ac.id, agung.marhaeni@pasca.undiksha.ac.id
}

\begin{abstract}
Abstrak
Penelitian ini bertujuan mengetahui pengaruh model pembelajaran berbasis masalah terhadap kemampuan berpikir tingkat tinggi dan kemampuan menanya dalam pembelajaran matematika. Penelitian ini merupakan quasi eksperimen dengan rancangan posttest only control Group Design. Populasi penelitian ini adalah siswa kelas V di gugus II Kecamatan Tampaksiring Kabupaten Gianyar yang berjumlah 76 siswa dengan sampel sebanyak dua kelas yang berjumlah 52 siswa yang dipilih dengan teknik random sampling. Data kemampuan berpikir tingkat tinggi dan kemampuan menanya masing-masing dikumpulkan dengan tes objektif dan tes uraian. Data yang diperoleh dianalisis menggunakan uji MANOVA. Hasil penelitian menunjukkan (1) terdapat perbedaan kemampuan berpikir tingkat tinggi antara siswa yang mengikuti pembelajaran dengan model pembelajaran berbasis masalah dan siswa yang mengikuti pembelajaran konvensional; (2) terdapat perbedaan kemampuan menanya antara siswa yang mengikuti pembelajaran dengan model pembelajaran berbasis masalah dan siswa yang mengikuti pembelajaran konvensional; (3) secara simultan terdapat perbedaan kemampuan berpikir tingkat tinggi dan kemampuan menanya antara siswa yang mengikuti pembelajaran dengan model pembelajaran berbasis masalah dan siswa yang mengikuti pembelajaran konvensional.
\end{abstract}

Kata kunci: kemampuan berpikir tingkat tinggi, kemampuan menanya, model pembelajaran berbasis masalah

\begin{abstract}
This research aimed at determining the effect of problem-based learning model on highlevel thinking abilities and questioning abilities in mathematics learning. This research was a quasi-experimental design with posttest only control Group Design. The research population was class V elementary school cluster II sub-district Tampaksiring Gianyar regency totaling 76 students with the samples of two classes totaling 52 students determined through random sampling techniques. The data on high-level thinking abilities and questioning abilities were collected through objective tests and analysis tests. The data collected were analyzed through the MANOVA test. The results showed that (1) there was a difference in high-level thinking skills between the students who attended the problem-based learning model and conventional learning; (2) there was a difference in questioning abilities between the students who attended the problem-based learning model and conventional learning; (3) simultaneously there was a difference in high-level thinking abilities and questioning abilities between the students who attended the problem-based learning model and the students who attended the conventional learning.
\end{abstract}

Keywords: high-level thinking abilities, questioning abilities, problem-based learning model 


\section{PENDAHULUAN}

Peningkatan berpikir tingkat tinggi telah menjadi salah satu prioritas dalam pembelajaran matematika di sekolah. Permen 22 Tahun 2006 (Standar Isi) menyatakan mata pelajaran Matematika diberikan kepada semua peserta didik untuk membekali mereka dengan kemampuan berpikir logis, analitis, sistematis, kritis, dan kreatif, serta kemampuan bekerjasama. Pembelajaran matematika sekolah bertujuan agar peserta didik memiliki kemampuan memecahkan masalah yang meliputi kemampuan memahami masalah. Guru sebagai ujung tombak perubahan dapat mengubah pola pikir dan strategi pembelajaran yang pada awalnya berpusat pada guru (teacher centered) berubah menjadi berpusat pada siswa (student centered). Guru diharapkan lebih kreatif dan inovatif dalam menyajikan materi pelajaran. Pembelajaran yang dapat diterapkan adalah pembelajaran dengan memberdayakan untuk berfikir tingkat tinggi (high order thinking).

Higher Order of Thinking Skill (HOTS) adalah kemampuan berpikir kritis, logis, reflektif, metakognitif, dan berpikir kreatif yang merupakan kemampuan berpikir tingkat tinggi. Higher Order of Thinking Skill (HOTS) atau kemampuan berpikir tingkat tinggi merupakan suatu kemampuan berpikir yang tidak hanya membutuhkan kemampuan mengingat saja, namun membutuhkan kemampuan lain yang lebih tinggi, seperti kemampuan berpikir kreatif dan kritis. Dengan demikian, kemampuan berfikir terutama berfikir tingkat tinggi harus dikembangkan dan menjadi bagian dari pelajaran matematika sehari-hari. Kemampuan berfikir dapat dikembangkan dengan cara membantu siswa menjadi problem solver yang lebih baik. Untuk itu, guru harus menyediakan masalah yang memungkinkan siswa menggunakan kemampuan berfikir tingkat tingginya.

Seperti yang disampaikan oleh Nogroho (2018:4) "HOTS akan memapukan siswa dalam mengonstruksi argumen yang tepat dan efektif untuk membuat keputusan atau solusi yang rasional. Mengajarkan siswa HOTS merupakan suatu kewajiban guru di zaman ini". Selanjutnya Nugroho (2018: 16) menegaskan bahwa, "Mendidik siswa harus dengan HOTS berarti menjadikan mereka mampu berpikir. Siswa dikatakan mampu berpikir jika dapat mengaplikasikan pengetahuan dan pengembangan kemampuan yang dimiliki dalam konteks situasi yang baru." Wulandari dan Jailani (2015) menyarankan bahwa untuk meningkatkan kualitas pendidikan di Indonesia, semua stakeholder harus memperhatikan higher-order thinking atau berpikir tingkat tinggi. Nizam (dalam Widana, 2017) menyatakan bahwa penilaian di Indonesia diarahkan pada model penilaian higher order thinking skills (HOTS). Kebijakan tersebut mengacu pada kebutuhan akan keterampilan hidup di abad 21.

Menurut Widaningsih (2019:134) Data hasil Programme for International Student Assesment (PISA), Trends in International Mathematics and Science Study (TIMSS), dalam tes IPA dan Matematika anak Indonesia hanya dapat mengerjakan tes dengan tingkat kesulitan di bawah level, satu sementara anak - anak Jepang dan Korea dapat mengerjakan tes dalam level $5-6$, yakni level yang paling tinggi. Widaningsih (2019:135) dari tahun 2007 hingga 2011 pencapaian anak-anak Indonesia dalam mengerjakan soal PISA selalu konsisten. Empat tahun kemudian walau ada perbaikan tetapi masih tetap belum mampu naik ke level tinggi. Hal ini menunjukkan sebuah tantangan untuk guru kita karena soal PISA lebih banyak problem solving dan critical thinking sedangkan pembelajaran kita lebih banyak pada hafalan, sehingga siswa kita sulit untuk menjawab soal, artinya tantangan bagi guru kita bagaimana meningkatkan kemampuan problem solving dan critical thinking pada siswa - siswa kita.

Mencermati lebih jauh permasalahanpermasalahan tersebut, akar permasalahannya adalah pemahaman konsep matematika. Jika peserta didik memahami konsep matematika, peserta didik dapat menggunakan berbagai rumus tanpa perlu menghafalnya, sehingga peserta didik akan mudah menemukan solusi dari permasalahan matematika. Penekananan penguasaan konsep ini dapat dilakukan dengan pembelajaran yang dapat 
memberikan kesan yang mendalam tentang konsep-konsep yang dipelajari. Hal ini akan mengakibatkan konsep tertanam lebih lama dalam diri peserta didik. Salah satu pembelajaran yang menekankan pemahaman konsep dan menekankan tertanamnya konsep lebih lama adalah dengan melibatkan peserta didik secara aktif dalam pembelajaran untuk membangun sendiri konsep yang dipelarinya. Pembelajaran seperti ini dikenal dengan pembelajaran dengan pendekatan yang beraliran konstruktivisme. Konstruktivisme merupakan pendekatan dalam psikologi yang berkeyakinan bahwa peserta didik dapat membangun atau membentuk pemahaman dan pengetahuannya sendiri tentang dunia di sekitarnya atau dengan kata lain, peserta didik dapat membelajarkan dirinya sendiri melalui berbagai pengalaman. Seperti yang disampaikan Trianto (2010:40) teori konstruktivis itu menyatakan bahwa siswa harus menenukan sendiri dan mentransformasikan informasi kompleks, mengecek informasi baru dengan aturanaturan lama dan merevisinya apabila aturan-aturan itu tidak lagi sesuai. Dengan demikian, pembelajaran dengan pendekatan konstruktivisme diartikan sebagai proses memperoleh pengetahuan yang diciptakan atau dilakukan oleh peserta didik sendiri melalui transformasi pengalaman individu peserta didik.

Salah satu pembelajaran yang sesuai dengan pendapat konstruktivis tersebut diantaranya adalah pembelajaran berbasis masalah. Trianto (2010:90) menyatakan, Model Problem Based Learning (Pembelajaran Berbasis Masalah) merupakan model pembelajaran yang didasarkan pada banyaknya permasalahan yang membutuhkan penyelidikan autentik yakni penyelidikan yang membutuhkan penyelesaian nyata dari permasalahan yang nyata. Pembelajaran berbasis pemecahan masalah dapat diartikan sebagai suatu pembelajaran yang di dalam pembelajarannya dihubungkan dengan pemberian masalah dan diakhiri dengan didapatkannya suatu penyelesaian dari permasalahan tersebut yang terfokus dan mengutamakan pengalaman peserta didik dalam belajar. Sebagaimana dikemukakan oleh shadiq (2009:13) model pembelajaran pemecahan masalah adalah suatu rancangan tindakan (action) yang dilakukan guru agar siswanya termotivasi untuk menerima tantangan yang ada pada pertanyaan (soal) dan mengarahkan siswa pada proses pemecahannya. Dalam hal ini, peserta didik secara aktif membangun pengetahuan yang dibutuhkan dari masalah yang diberikan. Peran aktif peserta didik dalam proses pembelajaran mengindikasikan bahwa pembelajaran berbasis masalah bukan proses transfer ilmu dari pendidik ke peserta didik tetapi pendidik sebagai fasilitator yang menyediakan masalah dan scaffolding yang dibutuhkan oleh peserta didik untuk mengkonstruksi pengetahuannya sendiri.

Pembelajaran dengan pembelajaran berbasis masalah berlangsung secara alamiah sehingga peserta didik bebas melakukan eksplorasi, memanfaatkan berbagai sumber belajar dan pengalaman belajar untuk menemukan pengetahuan dan pengalaman baru dalam kehidupan nyata sehari-hari. Pembelajaran berbasis masalah dimulai dengan penyajian masalah dan mengorganisasikan peserta didik untuk belajar. Kelompok-kelompok peserta didik kemudian membuat hipotesis dan merencanakan penyelidikan untuk menemukan pemecahan masalah. Perkembangan belajar peserta didik dipantau oleh pendidik dan oleh peserta didik itu sendiri. Tahap terakhir adalah tiaptiap kelompok mempresentasikan hasil temuannya, merefleksi, dan mencari jika terdapat solusi lain yang dapat memecahkan masalah yang disajikan. Dari sini terlihat bahwa tahap pertama dari pembelajaran berbasis masalah adalah penyajian masalah yang kemudian akan diselesaikan peserta didik.

Siswa diberi kesempatan untuk menganalisis dan memecahkan masalah nyata yang dihadapi dalah kehidupan sehari-hari sendiri yang dikaitkan dengan pembelajaran di dalam kelas. Model pembelajaran ini melibatkan siswa secara aktif menganalisis hingga memecahkan masalah nyata yang ada di lingkungannya hingga memperoleh konsep yang benar. Model pembelajaran berbasis masalah akan mampu menghubungkan antara apa 
yang dipelajari dengan bagaimana pemanfaatannya. Selain itu, siswa akan memiliki kemampuan untuk mencari pemecahan masalah serta pengetahuan yang meyertainya, menghasilkan pengetahuan yang bermakna melalui pemikiran sendiri. Karena dalam penerapan model pembelajaran ini siswa dibelajarkan untuk mencari pemecahan masalah secara mandiri yang akan memberikan pengalaman konkret. Sejalan dengan yang disampaikan oleh Suyatno (2009:9) bahwa dengan pembelajaran yang dimulai dari masalah, siswa belajar suatu konsep dan prinsip sekaligus pemecahan masalah. Pelatihan pemecahan masalah ini akan mendorong siswa untuk terlatih berpikir analisis bahkan sampai menghasilkan sesuatu dari buah pemikirannya. Oleh sebab itu, dapat disimpulkan dalam pembelajaran berbasis masalah akan dapat meningkatakan kemampuan siswa dalam berpikir tinggkat tinggi (HOTS). Hal ini senada dengan pernyataan Magsino (dalam Noma, dkk: 2016) bahwa model PBL dapat mengembangkan kemampuan berpikir tingkat tinggi pada peserta didik. Tan (dalam Noma, dkk: 2016) menyampaikan tahap-tahap model PBL, yaitu: meeting the problem, problem analysis and learning issues, discovery and reporting, solustion presentation and reflection, overview integration and evaluation. Selanjutnya Anderson dan Karthwohl, Khofifatin dan Yunata, Magsino, Tan (dalam Noma, dkk: 2016) menyatakan; Meeting the problem dapat meningkatkan kemampuan menganalisis (C4) melalui kegiatan mengidentifikasi fenomena yang dihadirkan dan merumuskan pertanyaan. Problem analysis and learning issues dapat meningkatkan kemampuan mencipta (C6) melalui kegiatan perencanaan penyelidikan dan menentukan jawaban sementara dari perumusan illstrcture, serta meningkatkan kemampuan menganalisis (C4) melalui kegiatan membedakan informasi yang penting dari informasi yang tidak penting untuk menentukan jawaban dari permasalah yang telah ditentukan. Discovery and reporting dapat meningkatkan kemampuan mengevaluasi (C5) melalui kegiatan memeriksa dan mengkritik ketika peserta didik melaporkan hasil penemuan yang telah dilakukan kepada masing-masing anggota kelompok dalam kegiatan diskusi. Solution presentation and reflection dapat meningkatkan kemampuan mengevaluasi (C5) melalui kegiatan Tanya jawab mengenai solusi pemecahan masalah. Overview, integration and evaluation dapat meningkatkan kemampuan evaluasi (C5) melalui kegiatan mengevaluasi proses pencarian solusi permasalahan dan meningkatkan kemampuan mencipta (C6) melalui kegiatan penarikan kesimpulan.

Selain meningkatkan keterampilan berpikir tingkat tinggi pada siswa, model pembelajaran berbasis masalah juga diharapkan mampu meningkatkan kemampuan menanya siswa. Seperti yang kita ketahui kemampuan menanya merupakan salah satu pengalaman belajar yang seharusnya dilalui oleh siswa dalam proses belajarnya. Menanya melatih siswa mengembangkan kreativitas, rasa ingin tahu, kemampuan merumuskan pertanyaan untuk membentuk pikiran kritis yang perlu untuk hidup cerdas dan belajar sepanjang hayat. Menanya adalah salah satu kompetensi yang diperlukan siswa untuk hidup di era cerdas abad 21.

Masalah yang terjadi adalah sampai saat ini kemampuan bertanya masih belum mendapat prioritas dalam pembelajaran, hal ini dikarenakan (1) guru kurang mampu menumbuhkan keberanian bertanya siswa, dimana dalam satu kelas biasanya hanya beberapa siswa yang aktif bertanya, sedangkan yang lain diam terpaku, (2) telah berakarnya mengajar dengan menggunakan metode ceramah yang cenderung menempatkan guru sebagai sumber informasi sedangkan siswa menjadi penerima informasi yang pasif, (3) latar belakang kehidupan anak dalam lingkungan keluarga dan masyarakat yang kurang biasa mengajukan pertanyaan dan menyatakan pendapat, (4) pandangan yang salah mengenai tujuan pertanyaan yang mengatakan bahwa pertanyaan hanya digunakan untuk mengevaluasi hasil belajar siswa (Wahyudiatmika, 2015).

Sedangkan di sisi lain, kebiasaan bertanya merupakan salah satu bagian penting guna menunjang tercapainya hasil 
belajar yang optimal. Hanifah \& Julia (2014:207) menyatakan guru sebagai motivator harus dapat memotivasi siswanya agar terbiasa bertanya, karena hail ini penting untuk mengembangkan mental siswa dalam penambah pengetahuan yang belum diketahui. Dalam kegiatan menanya, guru membuka kesempatan secara luas kepada peserta didik untuk bertanya mengenai fakta, konsep, prinsip atau prosedur yang sudah dilihat, disimak, dibaca atau dilihat. Guru perlu membimbing peserta didik untuk dapat menanya atau mengajukan pertanyaan: pertanyaan tentang hasil pengamatan objek yang konkrit sampai kepada yang abstrak berkenaan dengan fakta, konsep, prosedur, atau pun hal lain yang lebih abstrak. Siswa harus dilatih agar bisa menanya hal-hal yang bersifat faktual sampai kepada pertanyaan yang bersifat hipotetik. Dari situasi di mana peserta didik dilatih menggunakan pertanyaan dari guru, masih memerlukan bantuan guru untuk mengajukan pertanyaan sampai ke tingkat di mana peserta didik mampu mengajukan pertanyaan secara mandiri. Hanifah \& Julia (2014:200) menyatakan bertanya berguna bagi siswa karena dapat membuktikan dirinya mampu berpikir kritis sekaligus mampu untuk mengakrabkan diri kepada lingkungan sekitar. Sagala (dalam Hanifah \& Julia, 2014:200) mengemukan bahwa dalam sebuah pembelajaran yang produktif kegiatan bertanya berguna untuk: (1) menggali informasi; (2) mengecek pemahaman siswa, (3) membangkitkan respon pada siswa; (4) mengetahui sejauh mana keingintahuan siswa; (5) mengetahui hal-hail yang sudah diketahui siswa.

Penerapan model pembelajaran berbasis masalah diharapkan mampu meningkatkan kemampuan menanya siswa.

Melalui masalah yang dikemukakan dalam pembelajaran menggunakan model pembelajaran berbasis masalah, siswa memiliki kesempatan untuk mengembangkan kemampuan menanya. Masalah yang disampaikan melalui rangkaian peristiwa atau objek temuan di lingkungan sekitar yang memerlukan

Penelitian ini merupakan penelitian eksperimen dengan bentuk desain yang digunakan dalam penelitian ini adalah penelurusan lebih lanjut sebab, akibat, konsep yang mendasari temuan tersebut. Hal inilah yang harus diidentifikasi oleh siswa dengan menyajikan beberapa pertanyaan yang logis untuk mempermudah siswa dalam kegiatan dianalisis lebih lanjut. Pada pembelajaran ini siswa dilatih langsung untuk membuat pertanyaan yang nantinya dimanfaatkan oleh siswa sendiri, siswa mendapat pelatihan serta pengulangan dan dirasakan manfaatkan maka pembelajaran ini akan lebih bermakna.

Riadi (2016) dalam penelitiannya menyatakan bahwa berdasarkan hasil dan pembahasan, dapat disimpulkan bahwa pembelajaran matematika berbasis $\mathrm{PBL}$ dapat meningkatkan HOTS siswa. Selain itu penelitian dari Yoesoef (2015) dalam penelitiannya menyatakan bahwa 1 . Pembelajaran fisika dengan model Problem Based Learning dapat meningkatkan kemampuan menanya siswa. 2.

Pembelajaran fisika dengan model Problem Based Learning dapat meningkatkan penguasaan konsep fisika siswa. Hasil penelitian ini menunjukan bahwa model pembelajaran berbasis masalah memberi pengaruh terhadap kemampuan berpikir tingkat tinggi dan kemampuan menanya siswa.

Berdasarkan pada pemaparan di atas diduga dengan menerapkan model pembelajaran berbasis masalah pada mata pelajaran matematika di sekolah dasar dapat memberi pengaruh terhadap kemampuan berpikir tingkat tinggi dan kemampuan menanya siswa. Untuk membutikan secara ilmiah yang didukung oleh data empiris tentang permasalahan tersebut, maka dipandang perlu kiranya untuk melaksanakan penelitian yang berjudul pengaruh model pembelajaran berbasis masalah terhadap kemampuan berpikir tingkat tinggi dan kemampuan menanya dalam pembelajaran matematika Kelas V SD di Gugus II Kecamatan Tampaksiring Kabupaten Gianyar Tahun Pelajaran 2018/2019.

\section{METODE}

Desain kuasi eksperimental (quasi eksperimental design). Desain ini mempunyai kelompok kontrol, tetapi tidak 
dapat berfungsi sepenuhnya untuk mengontrol variabel-variabel luar yang mempengaruhi pelaksanaan eksperimen (Sugiyono, 2010:114). Desain penelitian ini dipilih karena tidak memungkinkan untuk dilakukan eksperimen sungguhan. Rancangan kuasai eksperimental yang digunakan dalam penelitian ini adalah posttest only control group design. Pada desain ini ada dua kelompok yang dipilih secara random. Kelompok pertama diberi perlakuan kemudian dilakukan pengukuran sedangkan kelompok kedua tidak diberikan perlakuan tetapi hanya dilakukan pengukuran saja.

Agung (2014:69) menyatakan,

Populasi adalah keseluruhan objek dalam suatu penelitian. Silaen dan Widiono (2013:87) menyatakan, Populasi yang dinotasikan dengan $\mathrm{N}$ adalah keseluruhan dari objek atau individu yang memiliki karakteristik (sifat-sifat) tertentu yang akan diteliti. Populasi dalam penelitian ini adalah siswa kelas V SD di Gugus II Kecamatan Tampaksiring Kabupaten Gianyar Tahun Pelajaran 2018/2019.

Agung (2014:47) menyatakan, sampel adalah sebagian dari populasi yang diambil, yang dianggap mewakili seluruh populasi dan diambil menggunakan teknik tertentu. Silaen dan Widiyono (2013:87) menyatakan, "sampel (notasi: n) adalah sebagian dari populasi yang diambil dengan cara tertentu untuk mengukur atau dimatai karakteristiknya, kemudian ditarik kesimpulan mengenai karakteristik tersebut yang dianggap mewakili populasi." Dengan demikian, dapat ditarik pengertian bahwa sampel adalah bagian dari jumlah dan karakteristik populasi yang ditentukan dengan mengunakan teknik tertentu." Teknik sampling yang digunakan dalam penelitian ini adalah teknik random sampling. Pada teknik ini, semua anggota dalam populasi memiliki kesempatan yang sama untuk dipilih menjadi sampel. Sampel dipilih tanpa adanya pemilihan individu sebagai sampel karena tidak memungkinkan mengubah kelas yang sudah terbentuk. Kelas-kelas yang dipilih sebagai sampel dibagi menjadi dua kelas, yaitu kelas eksperimen dan kelas kontrol. Sebelum sampel diundi, dilakukan uji kesetaraan. Uji kesetaraan populasi dilakukan dengan menggunakan $t$-test.

Berdasarkan hasil uji kesetaraan populasi, populasi pada penelitian ini adalah empat SD yaitu SDN 3 Tampaksiring, SDN 4 Tampaksiring, SDN 5 Tampaksiring dan SDN 7 Tampaksiring yang berjumlah 76 siswa. Berdasarkan hasil pengundian, yang menjadi sampel penelitian adalah siswa kelas $\mathrm{V}$ di SD Negeri 4 Tampaksiring dengan jumlah 24 siswa dan siswa kelas $V$ di SD Negeri 3 Tampaksiring dengan jumlah 28 siswa. Dengan demikian, Jumlah seluruh sampel pada penelitian ini adalah 52 siswa. Dari dua kelas yang terpilih tersebut dilakukan pengundian untuk menentukan kelas eksperimen dan kontrol. Berdasarkan hasil pengundian, yang dijadikan kelas eksperimen adalah kelas $V$ di SD Negeri 4 Tampaksiring dan siswa kelas $\mathrm{V}$ di SD Negeri 3 Tampaksiring dijadikan kelas kontrol. Kelas eksperimen diberikan perlakuan pembelajaran dengan model pembelajaran berbasis masalah dan kelas kontrol diberikan perlakuan pembelajaran konvensional.

Data yang dibutuhkan dalam penelitian ini adalah data kemampuan berpikir tingkat tinggidan kemampuan menanya. Metode yang digunakan untuk mengumpulkan data kemampuan berpikir tingkat tinggi adalah metode tes dengan jenis pilihan ganda. "tes pilihan ganda adalah tes yang berisikan pertanyaan atau pernyataan pada setiap butirnya dan telah disediakan beberapa pilihan jawaban, salah satunya merupakan kunci jawaban" (susetyo, 2015:102). Instrumen penelitian yang digunakan untuk mengukur kemampuan menanya siswa kelompok eksperimen dan kelompok kontrol, adalah tes kemampuan menanya berupa tes uaian. Tes uraian dipilih dengan asumsi bahwa dengan menjawab tes uraian, kemampuan 
menanya siswa lebih mudah diamati dibandingkan dengan menjawab tes objektif. "Tes uraian (esai) adalah soal yang mengandung pertanya atau tugas yang jawaban atau pengerjaan soal tersebut harus dilakukan dengan cara mengekspresikan pikiran peserta tes secara narasi" (Astiti, 2017:36).

Sebelum instrumen ini diuji cobakan ke lapangan maka dilakukan uji validitas isi Butir tes dinyatakan valid jika terdapat kecocokan antara butir dan indikator oleh mayoritas ahli. Uji validitas dalam penelitian ini dilakukan dua orang pakar. Instrumen yang telah dinilai oleh judges selanjutnya diuji cobakan di lapangan. Berdasarkan uji coba yang telah dilakukan,setelah dilakukan analisis terhadap instrumen kemampuan berpikir tingkat tinggi diperoleh hasil valid sebanyak 20 soal dan koefisien reliabilitas tes sebesar 0,716 dengan mempertimbangan tingkat kesukaran dan daya beda tes maka digunakan 14 soal sedangkan instrumen kemampuan menanya diperoleh soal yang valid sebanyak 17 soal dan koefisien reliabilitas tes sebesar 0.71 dan dengan mempertimbangan tingkat kesukaran dan daya beda tes maka digunakan 12 soal.

Teknik analisis deskriptif digunakan untuk mengetahui tinggi rendahnya kualitas dari variabel penelitian, yaitu kemampuan berpikir tingkat tinggi. Dan kemampuan menanya. Analisis deskriptif dilakukan dengan menghitung Mean, Median, Modus, dan Standar Deviasi. Analisis statistik yang digunakan dalam penelitian ini adalah independent sample $t$-test, dan multivariate analysis of variance (MANOVA) dibantu dengan SPSS 16.00 for windows. Semua pengujian hipotesis dilakukan pada taraf signifikansi $5 \%$.

\section{HASIL DAN PEMBAHASAN}

Data yang dianalisis pada penelitian ini adalah data hasil tes kemampuan berpikir tingkat tinggi dan hasil tes kemampuan menanya pada pembelajaran matematika siswa Kelas $\mathrm{V}$ pada kelompok eksperimen dan kelompok kontrol. Deskripsi data nilai akhir kemampuan berpikir tingkat tinggi dan kemampuan menanya yang memaparkan rata-rata, median, modus, varians, standar deviasi, varian, nilai minimum, nilai maksimum, dan rentangan nilai dikerjakan dengan bantuan program pengolah angka Microsoft Office Excel. Adapun rekapitulasi hasil deskripsi data dapat dilihat pada tabel berikut.

Tabel 01

Deskripsi Data Kemampuan Berpikir Tingkat Tinggi dan Kemampuan Menanya Kelompok Eksperimen dan Kelompok Kontrol

\begin{tabular}{|l|c|c|c|c|}
\hline \multicolumn{1}{|c|}{ Hasil Analisis } & A1Y1 & A2Y1 & A1Y2 & A2Y2 \\
\hline $\mathrm{n}$ & 24 & 28 & 24 & 28 \\
\hline Mean & 10,71 & 7,12 & 40,08 & 33,67 \\
\hline Median & 11 & 7 & 40,5 & 34 \\
\hline Modus & 12 & 5 & 41 & 35 \\
\hline Varian & 3,78 & 4,38 & 19,38 & 31,05 \\
\hline Standar Deviasi & 1,94 & 2,09 & 4,4 & 5,57 \\
\hline Minimum & 6 & 4 & 30 & 22 \\
\hline Maksimum & 14 & 12 & 48 & 44 \\
\hline Banyak Kelas & 6 & 6 & 6 & 6 \\
\hline Panjang Kelas & 2 & 2 & 4 & 4 \\
\hline
\end{tabular}

Keterangan :

A1Y1 : Deskripsi data kemampuan berpikir tingkat tinggi siswa yang mengikuti pembelajaran dengan model pembelajaran berbasis masalah.
A2Y1 : Deskripsi data kemampuan berpikir tingkat tinggi siswa yang mengikuti pembelajaran dengan pembelajaran konvensional.

A1Y2 : Deskripsi data kemampuan menanya siswa yang mengikuti 
pembelajaran dengan model pembelajaran berbasis masalah.

A2Y2 : Deskripsi data kemampuan menanya siswa yang mengikuti pembelajaran dengan pembelajaran konvensional.

Berdasarkan tabel 01 dapat dilihat bahwa kemampuan kemampuan berpikir tingkat tinggi kelompok siswa yang dibelajarkan dengan model pembelajaran berbasis masalah dengan jumlah siswa sebanyak 24 orang siswa, mean sebesar 10,71, median 11, modus 12, varian sebesar 3,78 dan standar deviasi 1,94. Sedangkan kelompok siswa yang dibelajarkan dengan pembelajaran konvensional sebanyak 28 orang siswa, mean adalah 7,12 dengan median 7, modus 5, varian sebesar 4,38 dan standar deviasi 2,09. Kemampuan menanya kelompok siswa yang dibelajarkan dengan model pembelajaran berbasis masalah dengan dengan jumlah siswa sebanyak 24 orang siswa, mean sebesar 40,08, median 40,5, modus 41 , varian sebesar 19,38 dan standar deviasi 4,4. Sedangkan kelompok yang dibelajarkan dengan pembelajaran konvensional dengan jumlah siswa sebanyak 28 orang siswa, mean adalah 33,67 dengan median 34 , modus 35 varian sebesar 31,05 dan standar deviasi 5,57. Dari data tersebut menunjukkan bahwa kemampuan kemampuan berpikir tingkat tinggi dan kemampuan menanya kelompok eksperimen yang dibelajarkan dengan model pembelajaran berbasis masalah lebih tinggi dari kelompok kontrol yang dibelajarkan melalui pembelajaran konvensional.

Uji normalitas dilakukan dengan bantuan SPSS 16.00 for windows. Berdasarkan hasil analisis diperoleh bahwa semua data nilai sig. > 0,05 maka sebaran data berdistribusi normal..

Uji homogenitas varians dilakukan dengan bantuan SPSS 16.00 for windows.. Berdasarkan hasil analisis diperoleh nilai sig. > 0,05. Dengan demikian data penelitian tersebut memiliki varian yang homogen.

Uji homogenitas matriks variankovarians dilakukan dengan menggunakan uji Barlett diperoleh bahwa harga Box's $\mathrm{M}=$ 2,067 dengan taraf signifikansi 0,05 maka harga Box's M yang diperoleh tidak signifikan karena signifikansi yang diperoleh $0,601>0,05$. Dengan demikian matriks varians-kovarians dari variabel terikat sama.

Uji kolinieritas variabel terikat menggunakan korelasi Product Moment. Berdasarkan hasil analisis diperoleh bahwa uji kolinieritas kemampuan kemampuan berpikir tingkat tinggi dan kemampuan menanya siswa pada kelas eksperimen menunjukkan taraf signifikansi 0,031>0,05 dengan demikian antara kemampuan kemampuan berpikir tingkat tinggi dan kemampuan menanya siswa pada kelas eksperimen tidak berkolerasi sedangkan uji kolinieritas kemampuan kemampuan berpikir tingkat tinggi dan kemampuan menanya siswa pada kelas kontrol menunjukkan taraf signifikansi $0,38>0,05$ dengan demikian antara kemampuan kemampuan berpikir tingkat tinggi dan kemampuan menanya siswa pada kelas kontrol tidak berkolerasi. sehingga analisis MANOVA dapat dilanjutkan.

Pengujian hipotesis pertama dianalisis dengan menggunakan independent sample $t$-test, diperoleh $t_{\text {hit }}=$ 6,328 dengan siginfikasi 0,000 lebih kecil dari taraf signifikansi $5 \%(\alpha=0,05){\text { maka } \mathrm{H}_{1}}$ diterima.

Model pembelajaran berbasis masalah pada penelitian ini memiliki keunggulan, yaitu pembelajaran menggunakan model pembelajaran berbasis masalah siswa diberi kesempatan untuk menganalisis dan memecahkan masalah nyata yang dihadapi dalam kehidupan sehari-hari sendiri yang dikaitkan dengan pembelajaran di dalam kelas. Berdasarkan proses yang terjadi dalam pembelajaran yang menggunakan model pembelajaran berbasis masalah, siswa menjadi aktif untuk mengkonstruksi pengetahuannya sendiri sehingga pengetahuan yang diperoleh siswa tidak akan mudah dilupakan karena berkaitan dengan kehidupan dunia nyata siswa. Pembelajaran dengan pembelajaran berbasis masalah berlangsung secara alamiah sehingga peserta didik bebas melakukan eksplorasi, memanfaatkan berbagai sumber belajar dan pengalaman belajar untuk menemukan pengetahuan 
dan pengalaman baru dalam kehidupan nyata sehari-hari. Siswa memecahkan masalah yang dijumpai di sekitarnya melalui analisis materi pembelajaran hingga menyampaikan hasil analisisnya. Berbeda dengan pembelajaran yang menggunakan model pembelajaran konvensional. Guru mencakoki siswa dengan konsep-konsep serta rumus-rumus begitu saja melalui metode ceramah. Dalam pembelajaran ini, pelatihan siswa dalam menganalisis juga sangat minim terjadi.

Hasil penelitian ini sejalan dengan hasil penelitian yang dilakukan oleh Royantoro, Febry., dkk (2018) dalam penelitiannya menyatakan bahwa terdapat pengaruh yang signifikan HOTS peserta didik yang diajar menggunakan model PBL dengan yang diajar menggunakan model konvensional.

Dengan demikian, terdapat perbedaan kemampuan berpikir tingkat tinggi antara siswa yang mengikuti pembelajaran dengan model pembelajaran berbasis masalah dan siswa yang mengikuti pembelajaran konvensional dalam pembelajaran matematika kelas $\mathrm{V}$ SD.

Pengujian hipotesis kedua menggunakan independent sample t-test dengan dk 50. Berdasarkan hasil analisis diperoleh $t_{\text {hit }}=5,278$ dengan siginfikasi 0,000 lebih kecil dari taraf signifikansi $5 \%$ $(\alpha=0,05)$ sehingga $\mathrm{H}_{1}$ diterima.

Kegiatan bertanya menjadi unsur penting dalam pembelajaran karena dengan bertanya siswa dapat menambah wawasannya dengan cara menggali informasi yang belum diketahuinya. Kemampuan menanya mengakibatkan siswa berpikir yang lebih luas atas pengalaman belajarnya. Melalui masalah yang dikemukakan dalam pembelajaran menggunakan model pembelajaran berbasis masalah, siswa memiliki kesempatan untuk mengembangkan kemampuan menanya. Masalah yang disampaikan melalui rangkaian peritiwa atau objek temuan di lingkungan sekitar yang memerlukan penelurusan lebih lanjut sebab, akibat, konsep yang mendasari temuan tersebut. Hal inilah yang harus diidentifikasi oleh siswa dengan menyajikan beberapa pertanyaan yang logis untuk mempermudah siswa dalam kegiatan dianalisis lebih lanjut. Pada pembelajaran ini siswa dilatih langsung untuk membuat pertanyaan yang nantinya dimanfaatkan oleh siswa sendiri, siswa mendapat pelatihan serta pengulangan dan dirasakan manfaatkan maka pembelajaran ini akan lebih bermakna. Berbeda dengan mengunakan model pembelajaran konvensional, guru hanya memberikan konsep atau informasi kepada siswa dan pembelajaran berpusat pada guru. Pada proses ini guru menyajikan dan mendemonstrasikan pengetahuan agar siswa dapat memahami materi yang disampaikan guru. Kegiatan belajar yang seperti ini cenderung membuat siswa menjadi pasif sehingga kurang dapat mengembangkan kemampuan menanya.

Hasil penelitian ini sejalan dengan hasil penelitian yang dilakukan oleh Yoesoef (2015) dalam penelitiannya menyatakan bahwa 1. Pembelajaran fisika dengan model Problem Based Learning dapat meningkatkan kemampuan menanya siswa. 2. Pembelajaran fisika dengan model Problem Based Learning dapat meningkatkan penguasaan konsep fisika siswa.

Dengan demikian, terdapat perbedaan kemampuan menanya antara siswa yang mengikuti pembelajaran dengan model pembelajaran berbasis masalah dan siswa yang mengikuti pembelajaran konvensional dalam pembelajaran matematika kelas $\mathrm{V}$ SD.

Uji Hipotesis ketiga dilakukan dengan uji $\mathrm{F}$ melalui MANOVA. Berdasakan hasil penelitian didapatkan nilai signifikansi Pillai's Trace, Wilks' Lambda, Hotelling' Trace, Roy's Largest Root sebesar 0,000 dan kecil dari 0,05 sehingga bahwa $\mathrm{H}_{0}$ ditolak dan $\mathrm{H}_{1}$ diterima.

Model Pembelajaran Berbasis masalah memberi kesempatan untuk mengembangkan kemampuan berpikir tingkat tinggi dan kemampuan menanya siswa. Penerapan model pembelajaran berbasis masalah menuntut proses memecahkan masalah sebagai fokus dalam pembelajaran. Siswa dilatih untuk menganalisis masalah selanjutnya siswa dibimbing untuk menyusun pertanyaantertanyaan. Siswa dilatih untuk 
mengungkapkan dugaan sementara, mengumpulkan informasi dan melakukan penyelidikan, menyampaikan hasil, hingga mengevaluasi hasil tersebut. Kegiatan tersebut akan melatih dan mematangkan kemampuan siswa untuk memecahkan masalah tingkat tinggi siswa dan kemampuan menanya siswa secara bersamaan.

Dibanding dengan menggunakan pembelajaran konvesional yang dalam kegiatan pembelajarannya didominasi oleh kegiatan ceramah oleh guru. Keterlibatan siswa sangat minim dalam kegiatan pembelajaran ini.

Hasil penelitian ini sejalan dengan penelitian oleh Rosidah (2018) penerapan model Problem Based Learning (PBL) dapat menumbuhkembangkan Higher Order Thinking Skill (HOTS) siswa Sekolah Dasar. Selanjutnya hasil penelitian yang dilakukan oleh Riadi (2016) dalam penelitiannya menyatakan bahwa berdasarkan hasil dan pembahasan, dapat disimpulkan bahwa pembelajaran matematika berbasis PBL dapat meningkatkan HOTS siswa. Selanjutnya, oleh Lamanepa (2018) dalam penelitiannya menyatakan bahwa (1) terdapat kecenderungan peningkatan kemampuan bertanya peserta didik dalam pembelajaran fisika pada siklus I dan II (2) terdapat peningkatan kemampuan pemecahan masalah fisika pada peserta didik fisika setelah diberlakukan dua siklus dengan menerapkan model Problem based learning (PBL).

Dengan demikian, dapat disimpulkan bahwa terdapat perbedaan secara simultan kemampuan berpikir tingkat tinggi dan kemampuan menanya antara siswa yang mengikuti pembelajaran dengan model pembelajaran berbasis masalah dan siswa yang mengikuti pembelajaran konvensional dalam pembelajaran matematika kelas $\mathrm{V}$ SD.

\section{PENUTUP}

Berdasarkan hasil pengujian hipotesis dan pembahasan, dapat ditarik simpulan sebagai berikut.

Pertama, terdapat perbedaan kemampuan berpikir tingkat tinggi antara siswa yang mengikuti pembelajaran dengan model pembelajaran berbasis masalah dan siswa yang mengikuti pembelajaran konvensional dalam pembelajaran matematika kelas V SD..

Kedua, terdapat perbedaan kemampuan menanya antara siswa yang mengikuti pembelajaran dengan model pembelajaran berbasis masalah dan siswa yang mengikuti pembelajaran konvensional dalam pembelajaran matematika kelas $\mathrm{V}$ SD.

Ketiga, terdapat perbedaan secara simultan kemampuan berpikir tingkat tinggi dan kemampuan menanya antara siswa yang mengikuti pembelajaran dengan model pembelajaran berbasis masalah dan siswa yang mengikuti pembelajaran konvensional dalam pembelajaran matematika kelas $\mathrm{V} S \mathrm{SD}$.

Berdasarkan simpulan penelitian yang telah dipaparkan di atas, maka dapat disarankan beberapa hal yaitu pertama, kepada guru diharapkan agar model pembelajaran berbasis masalah dapat dijadikan salah satu alternatif dalam proses pembelajaran, agar proses pembelajaran dapat lebih efektif. Kedua, kepada peneliti lain Penelitian ini dilakukan pada populasi dan materi pembelajaran yang terbatas. Para peneliti lain disarankan untuk melakukan penelitian terhadap model ini dengan populasi yang lebih besar dan materi pembelajaran yang lebih luas untuk mengetahui pengaruh model pembelajaran ini dalam materi pembelajaran yang berbeda. Dalam penelitian ini variabelnya juga dapat dikembangkan sehingga nantinya dapat memperoleh hasil pembelajaran yang lebih baik.

\section{DAFTAR RUJUKAN}

Agung, A. A. G. 2014. Buku Ajar Metodologi Penelitian Pendidikan. Malang: Aditya Media Publishing.

Astiti, Kadek Ayu. 2017. Evaluasi Pembelajaran. Yogyakarta: Andi.

Lamanepa, G. H., \& Panis, I. C. (2018). Peningkatan Kemampuan Bertanya dan Pemecahan Masalah Peserta Didik SMA dalam Pembelajaran Fisika Melalui Problem Based 
Learning. Jurnal Pendidikan, Matematika dan Sains, 3(1), 99-110.

Hanifah, N \& Julia. Prosiding Seminar Nasional Pendidikan Dasar Membedah Anatomi Kurikulum 2013 untuk Membangun Masa Depan Pendidikan yang Lebih Baik. Sumendang: Sumedang Press.

Noma, D, L., Prayitno, B, A., \& Suwarno. (2016). PBL Untuk Meningkatkan Kemampuan Berpikir Tingkat Tinggi Siswa Kelas $X$ SMA. Jurnal Bioedukasi, 9 (2), 62-66.

Nugroho, R Arifin. 2018. HOTS:High Order Thingking Skills. Jakarta: Gramedia Widiasarana Indonesia.

Ramadhan, F., Mahanal, S., \& Zubaidah, S. (2017). Kemampuan Bertanya Siswa Kelas X SMA Swasta Kota Batu pada Pelajaran Biologi. BIOEDUKASI (Jurnal Pendidikan Biologi), 8(1), 1115.

Riadi, A. (2016). Problem-based learning meningkatkan higher-order thinking skills siswa kelas VIII SMPN 1 Daha Utara dan SMPN 2 Daha Utara. Math Didactic: Jurnal Pendidikan Matematika, 2(3), 154-163.

Rosidah, C. T. (2018). Penerapan model problem based learning untuk menumbuhkembangkan higher order thinking skill siswa sekolah dasar. Jurnal inventa, 2(1), 62-71.

Royantoro, F., Mujasam, M., Yusuf, I., \& Widyaningsih, S. W. (2018). Pengaruh Model Problem Based Learning terhadap Higher Order Thinking Skills Peserta Didik. Berkala Ilmiah Pendidikan Fisika, 6(3), 371382.

Shadiq, Fadjar. 2009. Model-model Pembelajaran Matematika SMP. Jakarta: Depdiknas.

Silaen, Sofar dan Widiyono. 2013. Metodologi Penelitian Sosial untuk
Penulisan Skripsi dan Tesis.

Yogyakarta: In Media.

Sugiyono. 2010. Metode Penelitian Pendidikan (Pendekatan Kuantitatif, Kualitatif, dan R\&D). Bandung: Alfabeta.

Susetyo, B. 2015. Prosedur Penyusunan dan Analisis Tes untuk Penilaian Hasil Belajar Bidang Kognitif. Bandung: PT Refika Aditama.

Suyatno, 2009. Menjelajah Pembelajaran Inofatif. Sidoarjo: Masmedia Buana Pusaka.

Trianto. 2010. Mendesain Model Pembelajaran Inofatif-Progrsif:Konsep Landasan dan Implementasinya pada Kurikulum Tingkat Satuan Pendidikan (KTSP). Jakarta: Kencana.

Widana, I. W. (2017). Higher Order Thinking Skills Assessment (HOTS). JISAE: Journal of Indonesian Student Assesment And Evaluation, 3(1), 3244.

Widaningsih, I. 2019. Strategi dan Inovasi Pembelajaran Bahasa Indonesia di Era Revolusi Indrustri 4.0. Ponorogo: Uwais Inspirasi Indonesia.

Wahyudhiatmika, P., Putra, D. K. N. S., \& Abadi, I. B. G. S. (2015). Analisis Kemampuan Siswa dalam Menanya pada Proses Pembelajaran dengan Pendekatan Saintifik pada Kurikulum 2013 (Tema Sejarah Peradaban Indonesia) Di Kelas V Sd Negeri 7 Sesetan Tahun Ajaran 2014/2015. MIMBAR PGSD Undiksha, 3(1).

Wulandari, N. F. (2015). Jailani.(2015). Indonesian Students's Mathematics Problem Solving Skill in PISA and TIMSS. In Proceeding of International Conference On Research, Implementation And Education of Mathematics And Sciences 2015.

Yoesoef, A. (2015). Penerapan Model Problem Based Learning Untuk 
Vol.2 No 1, Pebruari 2018

ISSN: 2613-9553

Meningkatkan Kemampuan Menanya

Dan Penguasaan Konsep Fisika

Kelas X MIA 1 SMA Negeri 2 Kediri.

PINUS: Jurnal Penelitian Inovasi

Pembelajaran, 1. 